\title{
VÄITÖKSET
}

\section{Toimintakyky ja kuntoutus ovat monimerkityksellisiä käsitteitä ympärivuorokautisessa pitkäaikaishoidossa}

Toimintakyky on yleinen käsite ikääntymistutkimuksessa ja -politiikassa, ikääntyneiden hoidon ja palveluiden järjestämisessä sekä päivittäisessä hoitotyössä. Puhummeko kuitenkaan aina samasta asiasta, kun puhumme ikääntyneen ihmisen toimintakyvystä?

\section{Ikääntyneen ihmisen toimintakyky ja sen mittaaminen}

Toimintakyvystä puhuttaessa saatetaan tarkoittaa fyysistä toimintakykyä, kuten kykyä kävellä tietyn pituinen matka, nousta portaita tai säilyttää tasapaino. Ikääntyneen ihmisen toimintakykyä on tavallista kuitenkin jaotella fyysisen ulottuvuuden lisäksi kognitiiviseen, psyykkiseen ja sosiaaliseen toimintakykyyn. Kognitiivisella toimintakyvyllä tarkoitetaan kykyä vastaanottaa ja käyttää tietoa. Psyykkiseen ulottuvuuteen kuuluu tiedon käsittelyn lisäksi esimerkiksi mielenterveyteen ja päätöksentekoon liittyviä tekijöitä. Sosiaalinen toimintakyky tarkoittaa kykyä toimia sosiaalisissa suhteissa. Toimintakykyä hahmottamaan kehitetyt teoreettiset mallit ovat kehittyneet suuntaan, jossa tunnistetaan yksilön kykyjen lisäksi ympäristön merkitys. Toimintakykyä tulisi siis tarkastella yksilön ja hänen ympäristönsä vuorovaikutuksena. Usein ikääntyneen ihmisen toimintakyky määritelläänkin laajasti sellaisina toimintoina, joita ihmisen tarvitsee tai hän haluaa toteuttaa omassa ympäristössään.

Toimintakyky on monin tavoin hyödyllinen käsite. Mitä vanhempi ihminen on, sitä todennäköisemmin hänellä on useita kroonisia sai- rauksia. Pelkästään tieto sairauksista ei kuitenkaan kerro siitä, millainen vaikutus niillä on ihmisen arkeen ja elämään. Tällöin voidaan tarkastella sairauksien sijasta ihmisen toimintakykyä. Usein pyritäänkin hankkimaan tietoa ihmisen toimintakyvystä määriteltäessä esimerkiksi hänen palveluiden tarvettaan. Heikompi kyky suoriutua päivässä tärkeäksi koetuista tai tärkeänä pidetyistä tehtävistä tarkoittaa suurempaa tarvetta ulkopuoliselle tuelle tai avulle.

Miten toimintakykyä sitten voidaan tarkastella ja saada siitä tietoa? On kehitetty lukuisia erilaisia mittareita, joiden avulla voidaan tarkastella toimintakykyä eri näkökulmista. Toimintakykyä voidaan arvioida esimerkiksi toimintatestien avulla mittaamalla vaikkapa kävelynopeutta tai sitä, kuinka nopeasti ihminen pystyy nousemaan viisi kertaa tuolilta seisomaan. Toimintakykyä voidaan arvioida myös käyttämällä erilaisia haastattelulomakkeita, joissa voidaan esimerkiksi tiedustella, kykeneekö ihminen peseytymään tai pukeutumaan itsenäisesti, ohjattuna vai autettuna.

Toimintakyvyn eri osa-alueiden laajuudesta johtuen ikääntyneiden ihmisten toimintakyvyn arviointiin on kehitetty myös laajoja ja moniulotteisia mittaristoja, kuten RAI. RAI tulee sanoista Resident Assessment Instrument eli vapaasti suomennettuna asukkaan arviointiväline. RAI:ta on hyödynnetty kansainvälisesti, ja se on laajasti käytössä myös Suomessa. Toimintakyvyn arvioinnin ohella RAI toimii myös hoidon laadun, tarpeen ja seurannan välineenä.

Erilaisilla toimintakykymittareilla saatavaa tietoa hyödyntävät erityisesti tutkijat sekä so- 
siaali- ja terveydenhuollon toimijat ja päättäjät. Voidaan kuitenkin pohtia, vastaavatko päivittäisessä hoidossa käytetty toimintakykykäsite ja ajatukset sen tukemisesta näitä mittareita vai voiko käsitteen takaa löytyä muutakin.

\section{Toimintakyvyn arviointi ja ylläpitäminen keskeisiä ikääntymispolitiikan tavoitteita}

Ikääntyneen ihmisen toimintakyvyn arviointiin ja tukemiseen velvoitetaan lainsäädännössä. Niin sanottu vanhuspalvelulaki edellyttää ikääntyneen väestön palveluiden toteuttamista siten, että ne tukevat ikääntyneiden toimintakykyä. Laissa säädetään myös pitkäaikaisen hoidon toteuttamista ohjaavista periaatteista, joista yksi on se, että ikääntyneellä ihmisellä on oltava mahdollisuus osallistua toimintakykyä edistävään ja ylläpitävään toimintaan.

Viimeisten vuosien aikana vanhuspalvelulakia on uudistettu, ja uudistamisen myötä toimintakyvyn arviointi on saanut myös lainsäädännössä entistä merkittävämmän roolin, kun vuonna 2020 lakiin kirjattiin velvollisuus käyttää RAI-arviointivälinettä toimintakyvyn ja palvelutarpeen arvioinnissa.

Ikääntyneiden palveluiden laatusuositukset, joita sosiaali- ja terveysministeriö on julkaissut jo vuodesta 2001 lähtien, täydentävät ja tarkentavat vanhuspalvelulain tavoitteita. Laatusuosituksia pidetään tärkeinä ikääntyneiden palveluita ohjaavina dokumentteina. $\mathrm{Uu}-$ simmassa suosituksessa, vuonna 2020 julkaistussa laatusuosituksessa hyvän ikääntymisen turvaamiseksi ja palvelujen parantamiseksi, yhtenä tavoitteena on ikääntyneen väestön toimintakyvyn turvaaminen. Ikääntyneille tarkoitettujen palvelujen tulisi huomioida kuntoutuminen ja toimintakykyä ylläpitävä toiminta arjessa.

\section{Ympärivuorokautisessa pitkäaikais- hoidossa pyritään ylläpitämään toimintakykyä}

Väitöskirjassani tarkastelen käsityksiä toimintakyvystä ja kuntoutuksesta ympärivuorokautisen hoidon kontekstissa. Ympärivuorokautinen hoito tarkoittaa sitä, että henkilökuntaa ja apua on tarjolla vuorokauden ympäri. Pitkäaikaishoidolla puolestaan tarkoitetaan joko tehtyä päätöstä pitkäaikaishoidosta tai yli kolmen kuukauden asumisaikaa hoivayksikössä.

Suomessa ikääntyneiden ympärivuorokautista pitkäaikaishoitoa järjestetään niin kutsutussa laitoshoidossa eli vanhainkodeissa tai terveyskeskuksen pitkäaikaisosastoilla sekä tehostetussa palveluasumisessa. Näissä yksiköissä asui vuoden 2019 lopussa yhteensä yli 40000 75-vuotiasta tai sitä vanhempaa suomalaista. Heistä ylivoimaisesti suurin osa asui tehostetussa palveluasumisessa. Suomessa on jo useamman vuoden ajan vähennetty laitoshoitoa ja samaan aikaan lisätty tehostettua palveluasumista. Tehostettu palveluasuminen on avopalvelua, jossa asukas on maksanut yleensä erikseen vuokrastaan, hoidostaan ja muista palveluista sekä lääkkeistään. Vanhainkotihoito on puolestaan laitoshoitoa, jota lain mukaan voidaan tarjota ainoastaan, jos siihen on lääketieteelliset tai asiakasturvallisuuteen liittyvät perusteet. Käytännössä laitoshoidon ja tehostetun palveluasumisen yksiköt ovat usein vastanneet hyvin samankaltaisiin palvelutarpeisiin, ja asukkaiden toimintakyky on jo lähtökohtaisesti heikentynyt.

Ikääntyneiden ihmisten toimintakyvyn tukeminen nähdään tärkeänä erityisesti kotona asumisen mahdollistumisen ja ympärivuorokautisen hoidon tarpeen vähentämisen näkökulmasta. Silti ympärivuorokautisessa hoidossa asuvan ikääntyneen toimintakyky, sen arviointi ja toimintakyvyn tukeminen esimerkiksi erilaisten kuntouttavien toimintamallien avulla on aivan keskeinen osa ympärivuorokautista pitkäaikaishoitoa.Tämä siis siitäkin huolimatta, 
että ympärivuorokautisessa hoidossa asutaan usein elämän viimeisiä vuosia, jolloin toimintakyky on heikko ja heikkenee usein väistämättä.

Etsin käsiini tätä kirjoitusta varten muutaman kaupungin ympärivuorokautisen hoidon periaatteita. Niissä todetaan usein, että palveluntuottaja toteuttaa kuntoutumista edistävää työtapaa tai hoito perustuu kuntouttavan hoitotyön periaatteisiin. Palveluntuottajien lupaukset toimintakykyä ylläpitävästä toiminnasta osoittavat, että toimintakyvyn ylläpitämisen ja kuntouttamisen ideaalit toistuvat myös tavassa, jolla ympärivuorokautisen hoidon palveluita pyritään tuottamaan.

Kuntouttava tai kuntoutumista edistävä työote on yksi tärkeimmistä ikääntyneiden hoitotyötä ohjaavista toimintamalleista. Kuntouttavalla työotteella tarkoitetaan yleisesti tavoitteellista ja ihmisen toimintakyvyn vahvistamiseen ja ylläpitämiseen tähtäävää toimintaa. Kuntouttaminen ei ole kuitenkaan aivan yksiselitteistä. Kotihoidossa kuntoutuksella pyritään tukemaan ihmisen mahdollisuuksia asua omassa kodissaan mahdollisimman pitkään. Mutta mikä on kuntoutumisen tavoite ympärivuorokautisessa hoidossa, jossa asukkaat lähtökohtaisesti jo tarvitsevat apua vuorokauden ympäri?

\section{Ympärivuorokautinen hoiva ajankohtaisena aiheena}

Väitöskirjaa kirjoittaessani julkisessa keskustelussa nostettiin esille hoivakoteihin liittyvät laatuongelmat. Vuonna 2019 uutisoitiin ympärivuorokautisen hoidon yksiköissä esiin nousseista hoidon laatuun liittyneistä epäkohdista. Julkisuudessa puhuttiin hoivakriisistä. Tilannetta on edelleen vaikeuttanut koronaviruspandemia, jonka myötä vuonna 2020 läheisten ja perheenjäsenten vierailut hoivakoteihin kiellettiin tai ainakin niitä rajattiin rankasti. Tältä osin koronaviruspandemia on osaltaan korostanut perheenjäsenten merkitystä asukkaiden toimintakyvyn ylläpitämisessä.
Myös hoitajien työssäjaksaminen, joka on jo pitkään ollut hoivakodeissa huolen aiheena, paheni monin paikoin pandemian aikana. Vanhustyön vetovoimaisuus on viime aikoina herättänyt keskustelua. Huolta on herättänyt myös lakiin kirjatun ympärivuorokautisen pitkäaikaishoidon hoitajamitoituksen kasvun myötä tuleva työvoiman tarve.

Ympärivuorokautinen pitkäaikaishoito on siis tutkimuskohteena varsin ajankohtainen. Väestön vanhetessa ja kuoleman sijoittuessa yhä myöhäisempään ikään ympärivuorokautista hoitoa tarvitaan tulevaisuudessakin. Tarvitaan siis myös osaavia ja ammattitaitoisia hoitajia, jotka viihtyvät ja jaksavat työssään ikääntyneiden parissa.

\section{Väitöskirjassa tarkastellaan käsityksiä toimintakyvystä ja kuntoutuksesta}

Kun ikääntyneen ihmisen toimintakyvyllä ja siihen liittyvillä toiminnoilla, kuten toimintakyvyn arvioinnilla ja kuntoutuksella, on keskeinen rooli sekä ikääntymispolitiikassa että vanhojen ihmisten palveluiden järjestämisessä, ei ole aivan yhdentekevää, mitä toimintakyvyllä tarkoitetaan. Kun toimintakyvystä puhutaan paljon ja sen ylläpysymistä pidetään yhtenä tärkeimpinä tavoitteista, on hyvä kysyä: mitä toimintakyky oikeastaan on? Mitä toimintakyvyn ylläpitämisellä tavoitellaan? Tarkoittaako hyvä toimintakyky hyvää elämää ja arvokasta vanhuutta? Onko hoito silloin laadukasta, kun toimintakykyä kyetään ylläpitämään tai jopa parantamaan? Onko hoito epäonnistunut, jos ikääntyneen ihmisen toimintakyky heikkenee? Nämä kysymykset ovat erityisen mielenkiintoisia ympärivuorokautisessa hoidossa, jossa asuu jo lähtökohtaisesti toimintakyvyltään heikentyneitä ihmisiä ja tiedetään, että elämän loppuvaiheessa toimintakyky edelleen heikkenee.

Väitöskirjassani kysyn, miten ikääntyneen ihmisen toimintakyky ja kuntoutus ymmärretään ympärivuorokautisessa pitkäaikaishoidossa. Vastatakseni tähän kysymykseen olen haas- 
tatellut ympärivuorokautisen pitkäaikaishoidon asukkaita, heidän perheenjäseniään sekä hoitajia.

Ikääntyneen ihmisen toimintakyvyn kokonaisuuden hahmottamisessa ovat tärkeässä roolissa ihmisen itsensä sekä hänen läheisensä arviot toimintakyvystä ja avuntarpeesta. Keskeisessä asemassa ovat myös hoitotyöntekijät, joilta odotetaan objektiivista toimintakyvyn arviointia ja toimintakyvyn tukemista. Tutkimukseni tulokset antavat eväitä tarkastella ikääntyneiden ihmisten toimintakykyä ja sen tukemisen tapoja ympärivuorokautisessa pitkäaikaishoidossa eri toimijoiden näkökulmista. Tuon tutkimuksessani esille, miten ikääntyneen ihmisen toimintakyky määrittyy yhtäältä hoivapolitiikan ja sen sanaston ja toisaalta hoidon arjesta nousevien realiteettien kautta. Siksi ympärivuorokautisen hoidon suunnittelussa ja järjestämisessä on tärkeää huomioida paitsi poliittiset tavoitteet ja keinot myös hoidon arjen realiteetit ja edellytykset.

\section{Vilhelmiina Lehto-Niskala, Tt T}

vilhelmiina.lehto-niskala@tuni.fi

Gerontologian alaan kuuluva väitöskirja "Toimintakyky hoivapolitiikan ja hoidon arjen risteyksessä: Ikääntyneiden ympärivuorokautisen boidon asukkaiden, heidän perheenjäsentensä sekä hoitajien käsityksiä toimintakyvystä ja kuntoutuksesta" tarkastettiin Tampereen yliopistossa 27.8.2021.

\section{Kirjallisuutta}

Doh D, Smith R, Gevers P. Reviewing the reablement approach to caring for older people. Ageing Soc 2020;40(6):1371-83. https://doi.org/10.1017/S0144686X18001770

Finne-Soveri H, Hammar T, Noro A. Measuring the quality of long-term institutional care in Finland. Eurohealth 2010;16(2):8-10.

Guralnik J, LaCroix A. Assessing physical function in older populations. In: Wallace RB, Woolson RF, eds. The epidemiologic study of the elderly. New York: Oxford University Press, 1992:159-81. Heikkinen E, Laukkanen P, Rantanen T. Toiminta- kyvyn käsitteen ja arvioinnin evoluutio ja kehittämistarpeet. Teoksessa: Heikkinen E, Jyrkämä J, Rantanen T, toim. Gerontologia. Helsinki: Duodecim, 2013:278-83.

Hyttinen H. Ikäihminen hoitotyön asiakkaana. Teoksessa: Voutilainen P, Tiikkainen P, toim. Gerontologinen hoitotyö. Helsinki: WSOY Oppimateriaalit, 2009:41-56.

Koskinen S, Pitkälä K, Saarenheimo M. Gerontologinen kuntoutus. Teoksessa: Rissanen P, Kallanranta T, Suikkanen A, toim. Kuntoutus. 2. painos. Helsinki: Duodecim, 2008:547-65.

Laki ikääntyneen väestön toimintakyvyn tukemisesta sekä iäkkäiden sosiaali- ja terveyspalveluista 980/2012. Internet: https://www.finlex.fi/fi/laki/ ajantasa/2012/20120980 (viitattu 16.8.2021).

Lehto-Niskala V. Toimintakyky hoivapolitiikan ja hoidon arjen risteyksessä: ikääntyneiden ympärivuorokautisen hoidon asukkaiden, heidän perheenjäsentensä sekä hoitajien käsityksiä toimintakyvystä ja kuntoutuksesta. Tampereen yliopiston väitöskirjat 450. 2021.

http://urn.fi/URN:ISBN:978-952-03-2054-6

Metzelthin SF, Rostgaard T, Parsons M, Burton E. Development of an internationally accepted definition of reablement: A Delphi study. Ageing Soc 2020.

https://doi.org/10.1017/S0144686X20000999

STM. Laatusuositus hyvän ikääntymisen turvaamiseksi ja palvelujen parantamiseksi 2020-2023: tavoitteena ikäystävällinen Suomi. Sosiaali- ja terveysministeriön julkaisuja 2020:29.

THL. Mitä toimintakyky on? Internet: https://thl.fi/ fi/web/toimintakyky/mita-toimintakyky-on (viitattu 20.9.2021).

THL. Tietoa RAI-järjestelmästä. Internet: https:// thl.fi/fi/web/ikaantyminen/palvelutarpeiden-arviointi-rai-jarjestelmalla/tietoa-rai-jarjestelmasta (viitattu 20.9.2021).

Tiikkainen P, Heikkinen RL. Gerontologinen hoitotyö. Teoksessa: Heikkinen E, Jyrkämä J, Rantanen T, toim. Gerontologia. Helsinki: Duodecim, 2013:454-65.

Vähäkangas P. Toimintakykyä edistävä hoitotyö. Teoksessa: Voutilainen P, Tiikkainen P, toim. Gerontologinen hoitotyö. Helsinki: WSOY Oppimateriaalit. 2009:145-57.

WHO. Towards a common language for functioning, disability and health: ICF. Geneva: World Health Organization, 2002.

WHO. World report on ageing and health. Geneva: World Health Organization, 2015. 